\author{
https://doi.org/10.52449/1857-4114.2020.35-1.12
}

CZU: 799.322:159.9

\title{
EFFICIENCY OF THE TRAINING PROCESS FOR SUSTAINABLE DEVELOPMENT OF MENTAL PSYCHOTIC POTENTIAL TO 12-13 YEAR-OLD HANDBALL PLAYERS IN THEIR TEAM-GAME SPECIALIZATION
}

\author{
Verejan Ruslan ${ }^{1}$ \\ ${ }^{I}$ State University of Physical Education and Sport, Chisinau, Republic of Moldova
}

\begin{abstract}
This article provides information on the experimental effectiveness of the training process to 12-13 year-old handball players in their formed team-game specialization. Currently, the competition calendar has radically changed, it has become more dense and intense for teams of different levels and ages with high demands on the results of the competition. And this, in turn, creates difficulties in the training process of athletes, allowing an excessive intensification of training sessions, with all the ensuing consequences. We believe that in this situation, in order to improve the sports training of handball players, at the present stage, it is necessary to use other possible reserves, which suggest, against the background of general training processes, the restructuring of the existing ways of organizing game capabilities, including an earlier age-related team-game specialization of athletes, in which their role, as an individual sports and technical characteristic, will be especially effective in competitive manifestations.
\end{abstract}

Keywords: handball; 12-13-year-old handball players; types of motor activity; coordination opportunities; motor skills; team-game specialization; educational process; intellectual development; role; psycho-motor skills.

Actuality. The problems of training a sports reserve in handball are related to the improvement of sports and technical training of young athletes, to master motorcoordination capabilities, as well as teamgame coordination in competitive manifestations $[2,4,13,14,20,21]$. The traditionally developed system of training athletes in handball has exhausted itself and does not cause noticeable shifts in achieving goals, which leads specialists to search for new approaches, tools and training methods $[3,5,7$, $9,22]$.

The possibility of a targeted change in the system of the training process in handball was noted in the works of many authors $[6,8,10$, $12,15,18$ et all.].

It is quite natural that enthusiastic experts, scientists and other interested sports workers have been trying for many years to independently reform the system of sports training, including handball, on the one hand objectively and scientifically prove the need for organizational, structural and substantial transformations of the training process $[16,19]$, and on the other hand, officials directive determine this process and not for the better.

In our opinion, of particular interest, is the scientific research of a number of authors who tie the reform of sports training to the biological age periodization of children associated with the peculiarities of the functionality of their body and interests [17, 18]. It is worth highlighting such authors who prove the relationship of the intellectual state of children to training and their competitive success [11]. Other authors suggest reducing the age limit for intensive sports development 
$[2,8,10]$, and some prove the need to search for especially talented children for sports training and the transition to the commercialization of sports activities, which in our opinion is unnatural [5, 10, 23]. Moreover, a feature of the modern period on scientific achievements and developments, including sports development in handball, is the fact that there are no scientifically substantiated and effective forms, means and methods of sports improvement for practice for all age groups of young people in practice.

At the same time, it should also be noted that at the present stage of development in a difficult social environment, which imposes special requirements on the sports-training process for us, including the intellectual and physical nature. Currently, the calendar of competitions has radically changed, it has become denser and intense for teams of various levels and ages with high requirements for the results of competitions. And this in turn creates difficulties in the training process of athletes, allowing excessive intensification of training sessions, with all the ensuing consequences. To this it is necessary to add, extremely inadequate material and technical support for sports, including handball.

That is why we believe that in this situation, to improve the sports training of handball players, at the present stage, it is necessary to use other possible reserves, which suggest, against the background of general training processes, the restructuring of existing ways of organizing game opportunities, including to an earlier age team -gaming specialization of athletes in which their role, as an individual sports and technical characteristic, will be especially effective in competitive manifestations.

Thus, in our opinion, the solution to this problem is relevant and important for the sports improvement of handball players in the modern conditions of the development of sports in the Republic of Moldova.

The aim. Experimentally determine the effectiveness of the training process of 12-13 year-old handball players, taking into account their team-game specialization.

Objectives. A study of the effectiveness of the development of a complex of psychomotor manifestations of 12-13 years old handball players in the training process with the formed team-game roles.

Research organization. The experimental and pedagogical effect of the program material on the formation of the early team-game specialization of 12-13-year-old handball players on their morpho-functional, motor, coordination, psychomotor, intellectual, motor-coordination state was studied during the calendar year in a sports school. At the same time, the main pedagogical experiment was conducted with two groups of handball players - control and experimental (16 people each). At the same time, the control group of 12-13-year-old handball players trained according to the usual sports-training methodology for their own sports improvement. And an experienced group of handball players of 12-13 years of age trained according to a special Program, which provided for the training of handball players in playing roles. Moreover, in training sessions in the experimental group of handball players, all types of specialized training characteristic of the game role were carried out.

\section{Research results and their discussion.} At the beginning and at the end of the pedagogical experiment, handball players of both groups were tested, according to the results of which a comparative analysis was carried out in order to identify the effectiveness of the applied training tools and methods on their morpho-functional, motor, coordination, psychomotor and intellectual development.

To assess the morphological and psychomotor state of the body of the tested handball players participating in the main pedagogical experiment, we used anthropometry using tests that measure: weight, height, lung capacity. Psycho-motor tests: tapping test and sensory-motor reactions 
to sound and light signals (stimuli). Together, the results of these tests testified to how the means and methods used by us to form the applied (role) specialized abilities of 12-13 year-old handball players of experimental groups affected their morphological and psychomotor state. Table 1 shows the results of a comparative analysis of the results of the morphological and psychomotor state of the handball players participating in the main experiment. As can be seen from Table 1, all indicators reflect the state of the athletes of the studied groups, which they achieved during the experiment, and which for the most part correspond to their age development.

The obtained growth indicators of the studied handball players at the initial stage of the experiment in the studied groups show that they are relatively uniform at $\mathrm{P}>0.05$ and have relatively equally important characteristics of their identity in this test.

Table 1. A comparative analysis of the results of testing the morphological and psychomotor state of 12-13 years old handball players in the control and experimental groups for the period of the main study

\begin{tabular}{|c|c|c|c|c|c|c|}
\hline № & Types of Testing & 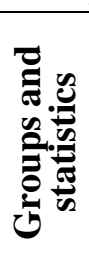 & $\begin{array}{c}\text { Initial indices } \\
\bar{X} \pm m\end{array}$ & $\begin{array}{c}\text { Final indices } \\
\bar{X} \pm m\end{array}$ & $\mathbf{t}$ & $\mathbf{P}$ \\
\hline \multirow{4}{*}{1.} & \multirow{4}{*}{ Height $(\mathrm{cm})$} & $\mathrm{C}$ & $166,97 \pm 4,67$ & $170,69 \pm 4,65$ & 0,82 & $>0,05$ \\
\hline & & $E$ & $166,44 \pm 4,62$ & $172,48 \pm 4,60$ & 1,35 & $>0,05$ \\
\hline & & $\mathrm{t}$ & 0,08 & 0,27 & - & - \\
\hline & & $\mathrm{P}$ & $>0,05$ & $>0,05$ & - & - \\
\hline \multirow{4}{*}{2.} & \multirow{4}{*}{ Weight (кг) } & $\mathrm{C}$ & $54,94 \pm 1,53$ & $56,50 \pm 1,50$ & 1,07 & $>0,05$ \\
\hline & & $E$ & $54,75 \pm 1,51$ & $57,75 \pm 1,50$ & 2,95 & $>0,05$ \\
\hline & & $\mathrm{t}$ & 0,09 & 0,59 & - & - \\
\hline & & $\mathrm{P}$ & $>0,05$ & $>0,05$ & - & - \\
\hline \multirow{4}{*}{3.} & \multirow{4}{*}{$\begin{array}{c}\text { Spirometry } \\
\text { Lung capacity (1) }\end{array}$} & $\mathrm{C}$ & $2,62 \pm 0,07$ & $2,68 \pm 0,06$ & 0,94 & $>0,05$ \\
\hline & & $E$ & $2,66 \pm 0,08$ & $2,85 \pm 0,05$ & 2,71 & $<0,05$ \\
\hline & & $\mathrm{t}$ & 0,36 & 2,12 & - & - \\
\hline & & $\mathrm{P}$ & $>0,05$ & $<0,05$ & - & - \\
\hline \multirow{4}{*}{4} & \multirow{4}{*}{$\begin{array}{c}\text { Tapping test } \\
\text { ( number of strokes } \\
\text { in } 40 \mathrm{sec} \text { ) }\end{array}$} & $\mathrm{C}$ & $321,06 \pm 10,54$ & $328,74 \pm 10,36$ & 0,76 & $>0,05$ \\
\hline & & $\mathrm{E}$ & $323,74 \pm 10,51$ & $358,90 \pm 10,22$ & 3,50 & $<0,01$ \\
\hline & & $\mathrm{t}$ & 0,18 & 2,07 & - & - \\
\hline & & $\mathrm{P}$ & $>0,05$ & $<0,05$ & - & - \\
\hline \multirow{4}{*}{5} & \multirow{4}{*}{$\begin{array}{l}\text { Sensor-motor } \\
\text { reaction to light }(\mathrm{sec})\end{array}$} & $\mathrm{C}$ & $0,37 \pm 0,03$ & $0,35 \pm 0,02$ & 1,00 & $>0,05$ \\
\hline & & $E$ & $0,38 \pm 0,03$ & $0,30 \pm 0,01$ & 2,67 & $<0,05$ \\
\hline & & $\mathrm{t}$ & 0,33 & 2,25 & - & - \\
\hline & & $\mathrm{P}$ & $>0,05$ & $<0,05$ & - & - \\
\hline \multirow{4}{*}{6} & \multirow{4}{*}{$\begin{array}{l}\text { Sensor-motor } \\
\text { reaction to sound } \\
(\mathrm{sec})\end{array}$} & $\mathrm{C}$ & $0,34 \pm 0,03$ & $0,32 \pm 0,03$ & 0,67 & $>0,05$ \\
\hline & & $\mathrm{E}$ & $0,32 \pm 0,03$ & $0,23 \pm 0,02$ & 4,50 & $<0,001$ \\
\hline & & $\mathrm{t}$ & 0,50 & 2,25 & - & - \\
\hline & & $\mathrm{P}$ & $>0,05$ & $<0,05$ & - & - \\
\hline
\end{tabular}

Note: $\mathrm{n}_{\mathrm{k}}-16 ; \mathrm{n}_{\mathrm{o}}-16 . \mathrm{P}-0,05 ; 0,01 ; 0,001$. $\mathbf{C}$ - control group; $\mathbf{E}$ - experimental group. $\mathrm{f}-15 \quad \mathrm{t}=2,131 \quad 2,947 \quad 4,073 \quad \mathrm{t}$ and $\mathrm{P}-$ statistical characteristics. $\mathrm{f}-30 \mathrm{t}=2,042 \quad 2,750 \quad 3,646 \quad \mathrm{r}=0,532$

At the same time, the dynamics of the growth indicators of handball players shows that by the end of the experiment, these results in both groups were significantly increased, 
which is a natural process of their physiological development. At the same time, such dynamics is statistically unreliable, including between groups " $E$ " and " $C$ " at the end of the experiment $(\mathrm{P}>0.05)$. Moreover, this fact has another significant feature, which indicates that the training tools used did not negatively affect the age-related development of the growth of handball players.

The situation is almost the same for experimental observation of handball players' weight indicators, which is also visible from Table 1. So, at the beginning of the study, the studied groups (control and experimental) also had a relatively uniform state in terms of weight characteristics at $\mathrm{P}>0.05$. At the same time, the control and experimental groups of handball players improved their weight results by the end of the experiment, but such an increase is ambiguous. At the same time, the control group of handball players did not significantly increase their body mass index (at $\mathrm{P}>0.05$ ), while the experimental group, intensively engaged in the formation of specialized role abilities, exceeded its weight indicator due to an increase in its own muscle mass.

It should also be noted that indicators of lung capacity, reflecting the functioning of the pulmonary system of handball players of the experimental groups at the beginning of the experiment, were relatively uniform at $\mathrm{P}>0.05$, and during the experiment changed for the better, but not the same. So, in the control group of handball players, the results of this test for the period of the one-year experiment improved, but not significantly at $\mathrm{P}>0.05$. At the same time, in the experimental group there was a noticeable and significant improvement in lung capacity (at $\mathrm{P}<0.05$ ), stably reflecting the positive impact of specialized (role) training tools on the functionality of the respiratory system of handball players. At the end of the experiment, the handball players of the experimental group also significantly exceeded their peers from the control group in this test, with $\mathrm{P}<0.05$.
As already noted, the psycho-motor properties of handball players are an important factor in their functional-motor manifestations and require study in various situational circumstances. So, when observing the motor manifestations of handball players, it is necessary to know their psycho-motor state, which will exclude the abstractness of the perception of their motor capabilities, and create a holistic view of physical fitness, including specialized.

When testing the state of psycho-motility of the studied handball players, the obtained indicators allowed us to study the functional state of the central and peripheral nervous system of their body (direct and feedback) using elementary motor ("motor") actions.

The functional stability of the neuromuscular system of the tested handball players was allowed to reveal the "tapping test", which determined the total, maximum possible frequency of the installation movements of the hand of the subject. The obtained research data for this test are also shown in Table 1, which also shows a comparative analysis of the studied parameters. As can be seen from Table 1, according to similar indicators, the handball players of the experimental groups in the "tapping test" were relatively homogeneous, at $\mathrm{P}>0.05$. At the same time, the control group of handball players improved their results by the end of the experiment in this test, but this improvement is unreliable, at $\mathrm{P}>0.05$. As for the experimental group of handball players, these athletes, by the end of the experiment, significantly and reliably improved their results with a high level of significance (at $\mathrm{P}<0.01$ ). Moreover, a comparative analysis of the results obtained at the end of the experiment also showed the superiority of the experimental group in fine motor skills over the control group of handball players. From this we can conclude that specialized software tools and methods for the formation of role-playing gaming abilities positively affect the handball players' motor skills they need in game situations. 
Table 1 presents the experimental data obtained by testing the sensorimotor reactions to the sound and light signals of the tested handball players. As can be seen from Table 1, both in the response to the sound and light signals, in the experimental group of handball players, the results obtained at the end of the experiment are significantly and reliably higher than in the control group of subjects, at $\mathrm{P}<0.05-0.01$.

Thus, the training process of specialized sports improvement organized by us in the experimental group of handball players positively affected their morpho-functional status and psycho-motricity. At the same time, in the control group of handball players, such significant changes did not occur.

The study of the dynamics of basic physical fitness, reflecting the state of the physical qualities of the handball players of the studied groups for the period of the pedagogical experiment, was carried out according to tests that in a complex reflected physical fitness. Table 2 shows the obtained test results of the handball players of the experimental groups for each test under study for the study period. As can be seen from Table 2, all the initial results of the handball players of the studied groups (in the Table, the vertical column "Initial indicators") are relatively homogeneous and relatively unreliable (at $\mathrm{P}>0.05$ ) for all the tests studied, which met the requirements for standard conditions and measurement procedures in the study. Further development of events showed that by the end of the main study stage the results of handball players changed ambiguously.

So, by the end of the main study, the control and experimental groups of handball players (letters $\mathrm{C}$ and $\mathrm{E}$ ) for the calendar year improved their performance for each test. As can be seen from Table 2, all the final indicators of the control group of athletes are statistically unreliable with respect to the initial results $(\mathrm{P}>0.05)$. At the same time, the results of the experimental group of handball players by the end of the experiment significantly, with high reliability, improved their achievements in all tests compared to the initial results at $\mathrm{P}<0.05-0.01$.

At the same time, by the end of the experiment they were more successful both in speed of movements and in speed manifestations, and in speed-strength abilities and in flexibility. Moreover, at the end of the study, the experimental group of handball players in their results in all tests also significantly prevailed over peers from the control group at $\mathrm{P}<0.05$.

Thus, the presented successes of the handball players of the experimental group showed that the means and methods of specialized installation and role development planned by us in the experimental Program were quite effective in forming the age-related motor status of the tested athletes.

Our main pedagogical research also involved the study of the development of the coordination capabilities of handball players in the annual cycle of the experiment. So, the control group of handball players traditionally was engaged only in the training process, without directed game specialization, while the experimental group developed its role-based coordination and applied capabilities in training according to our experimental program. At the same time, at the beginning and at the end of the main study, handball players of the experimental groups were tested and their results reflected the variety of manifestations of the coordination abilities of the subjects. All applied types of tests comprehensively characterized the variety of manifestations of coordination capabilities in the competitive process. 
Table 2. A comparative analysis of the results of testing the motor condition of 12-13 years old handball players in the control and experimental groups for the period of the main study

\begin{tabular}{|c|c|c|c|c|c|c|}
\hline № & Types of Testing & 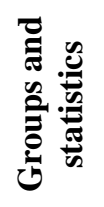 & $\begin{array}{l}\text { Initial indices } \\
\qquad \bar{X} \pm m\end{array}$ & $\begin{array}{c}\text { Final indices } \\
\bar{X} \pm m\end{array}$ & $\mathbf{t}$ & $\mathbf{P}$ \\
\hline \multirow{4}{*}{1.} & \multirow{4}{*}{$\begin{array}{l}\text { Running at a distance } \\
\text { of } 30 \mathrm{~m}(\mathrm{sec})\end{array}$} & $\mathrm{C}$ & $5,57 \pm 0,23$ & $5,39 \pm 0,21$ & 0,86 & $>0,05$ \\
\hline & & $\mathrm{E}$ & $5,50 \pm 0,22$ & $4,80 \pm 0,18$ & 3,50 & $<0,01$ \\
\hline & & $\mathrm{t}$ & 0,22 & 2,11 & - & 一 \\
\hline & & $\mathrm{P}$ & $>0,05$ & $<0,05$ & - & - \\
\hline \multirow{4}{*}{2.} & \multirow{4}{*}{$\begin{array}{l}\text { Flexion and extension } \\
\text { of the arms with } \\
\text { emphasis on the } \\
\text { gymnastic bench } \\
\text { (number of times) }\end{array}$} & $\mathrm{C}$ & $7,74 \pm 0,47$ & $8,25 \pm 0,45$ & 1,19 & $>0,05$ \\
\hline & & $\mathrm{E}$ & $7,76 \pm 0,50$ & $9,60 \pm 0,44$ & 4,08 & $<0,001$ \\
\hline & & $\mathrm{t}$ & 0,03 & 2,14 & - & - \\
\hline & & $\mathrm{P}$ & $>0,05$ & $<0,05$ & - & - \\
\hline \multirow{4}{*}{3.} & \multirow{4}{*}{ Triple jump (cm) } & $\mathrm{C}$ & $538,31 \pm 7,35$ & $543,77 \pm 7,30$ & 0,77 & $>0,05$ \\
\hline & & $\mathrm{E}$ & $541,50 \pm 7,30$ & $565,30 \pm 7,00$ & 3,44 & $<0,01$ \\
\hline & & $\mathrm{t}$ & 0,31 & 2,13 & - & - \\
\hline & & $\mathrm{P}$ & $>0,05$ & $<0,05$ & - & - \\
\hline \multirow{4}{*}{4.} & \multirow{4}{*}{$\begin{array}{l}\text { Torso forward from } \\
\text { standing while } \\
\text { standing on a } \\
\text { gymnastic bench }(\mathrm{cm})\end{array}$} & $\mathrm{C}$ & $6,02 \pm 0,31$ & $6,34 \pm 0,30$ & 1,10 & $>0,05$ \\
\hline & & $\mathrm{E}$ & $6,18 \pm 0,33$ & $7,22 \pm 0,30$ & 3,47 & $<0,01$ \\
\hline & & $\mathrm{t}$ & 0,35 & 2,10 & - & - \\
\hline & & $\mathrm{P}$ & $>0,05$ & $<0,05$ & - & - \\
\hline \multirow{4}{*}{5.} & \multirow{4}{*}{$\begin{array}{l}\text { Dynamometry of the } \\
\text { comfortable wrist, } \\
(\mathrm{kg})\end{array}$} & $\mathrm{C}$ & $18,78 \pm 0,28$ & $19,18 \pm 0,26$ & 1,60 & $>0,05$ \\
\hline & & $\mathrm{E}$ & $18,90 \pm 0,31$ & $20,09 \pm 0,27$ & 4,25 & $<0,001$ \\
\hline & & $\mathrm{t}$ & 0,28 & 2,46 & - & - \\
\hline & & $\mathrm{P}$ & $>0,05$ & $<0,05$ & - & - \\
\hline \multirow{4}{*}{6.} & \multirow{4}{*}{$\begin{array}{l}\text { Dynamometry of the } \\
\text { uncomfortable wrist, } \\
(\mathrm{kg})\end{array}$} & $\mathrm{C}$ & $16,43 \pm 0,44$ & $16,93 \pm 0,43$ & 1,22 & $>0,05$ \\
\hline & & $\mathrm{E}$ & $16,60 \pm 0,45$ & $18,20 \pm 0,40$ & 4,00 & $<0,01$ \\
\hline & & $\mathrm{t}$ & 0,27 & 2,15 & - & - \\
\hline & & $\mathrm{P}$ & $>0,05$ & $<0,05$ & - & - \\
\hline
\end{tabular}

Note: $\mathrm{n}_{\mathrm{k}}-16 ; \mathrm{n}_{\mathrm{o}}-16 . \mathrm{P}-0,05 ; 0,01 ; 0,001 . \mathbf{C}$ - control group; $\mathbf{E}$ - experimental group.

$$
\begin{aligned}
& \mathrm{f}-15 \quad \mathrm{t}=2,131 \quad 2,947 \quad 4,073 \quad \mathrm{t} \text { and } \mathrm{P} \text { - statistical characteristics. } \\
& \mathrm{f}-30 \quad \mathrm{t}=2,042 \quad 2,7503,646 \quad \mathrm{r}=0,532
\end{aligned}
$$

The obtained initial and final results of testing handball players of the studied groups, as well as comparing them with the proper indicators, are presented in Table 3 . As can be seen from Table 3, all the initial indicators of the studied groups (letters $\mathrm{C}$ and $\mathrm{E}$ ) are relatively uniform for each test at $\mathrm{P}>0.05$ (initial indicators - left column), which testified to their relatively equal initial conditions for coordination-motor status. 
Table 3. Comparative analysis of the results of testing the coordination capabilities of 12-13 years old handball players in the control and experimental groups for the period of the main study

\begin{tabular}{|c|c|c|c|c|c|c|}
\hline № & Types of Testing & 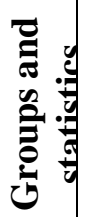 & $\begin{array}{l}\text { Initial indices } \\
\qquad \bar{X} \pm m\end{array}$ & $\begin{array}{l}\text { Final indices } \\
\qquad \bar{X} \pm m\end{array}$ & $\mathbf{t}$ & $\mathbf{P}$ \\
\hline \multirow{4}{*}{1.} & \multirow{4}{*}{$\begin{array}{c}3 \times 8 \text { m shuttle run, with } \\
\text { conducting a handball } \\
\text { ball (s.) }\end{array}$} & $\mathrm{C}$ & $5,78 \pm 0,22$ & $5,57 \pm 0,20$ & 1,05 & $>0,05$ \\
\hline & & $\mathrm{E}$ & $5,70 \pm 0,21$ & $4,98 \pm 0,18$ & 3,79 & $<0,01$ \\
\hline & & $\mathrm{t}$ & 0,26 & 2,18 & - & - \\
\hline & & $\mathrm{P}$ & $>0,05$ & $<0,05$ & - & - \\
\hline \multirow{4}{*}{2.} & \multirow{4}{*}{$\begin{array}{l}\text { Flexion and extension } \\
\text { of the arms with } \\
\text { emphasis on the floor } \\
\text { with a clap of palms , } 10 \\
\text { s. (number of times) }\end{array}$} & $\mathrm{C}$ & $5,15 \pm 0,47$ & $5,66 \pm 0,45$ & 1,19 & $>0,05$ \\
\hline & & $\mathrm{E}$ & $5,17 \pm 0,50$ & $7,01 \pm 0,44$ & 4,08 & $<0,001$ \\
\hline & & $\mathrm{t}$ & 0,03 & 2,14 & - & - \\
\hline & & $\mathrm{P}$ & $>0,05$ & $<0,05$ & - & - \\
\hline \multirow{4}{*}{3.} & \multirow{4}{*}{$\begin{array}{l}\text { Throwing a ball of the } \\
\text { second size, in a wall } \\
\text { target , } 10 \mathrm{~s} \text {. (number of } \\
\text { times) }\end{array}$} & $\mathrm{C}$ & $5,88 \pm 0,43$ & $6,20 \pm 0,40$ & 0,82 & $>0,05$ \\
\hline & & $\mathrm{E}$ & $6,10 \pm 0,44$ & $7,65 \pm 0,35$ & 4,08 & $<0,01$ \\
\hline & & $\mathrm{t}$ & 0,36 & 2,74 & - & - \\
\hline & & $\mathrm{P}$ & $>0,05$ & $<0,05$ & - & - \\
\hline \multirow{4}{*}{4} & \multirow{4}{*}{$\begin{array}{l}\text { Throwing a ball of the } \\
\text { second size at a } \\
\text { distance, standing (m) }\end{array}$} & $\mathrm{C}$ & $22,81 \pm 0,76$ & $23,45 \pm 0,74$ & 0,89 & $>0,05$ \\
\hline & & $\mathrm{E}$ & $23,17 \pm 0,77$ & $26,61 \pm 0,72$ & 3,39 & $<0,01$ \\
\hline & & $\mathrm{t}$ & 0,33 & 2,10 & - & - \\
\hline & & $\mathrm{P}$ & $>0,05$ & $<0,05$ & - & - \\
\hline \multirow{4}{*}{5} & \multirow{4}{*}{$\begin{array}{l}\text { Throwing of a handball } \\
\text { ball up, sitting, getting } \\
\text { up and catching the ball, } \\
30 \mathrm{~s} \text {, (number of times) }\end{array}$} & $\mathrm{C}$ & $5,89 \pm 0,37$ & $6,18 \pm 0,35$ & 0,85 & $>0,05$ \\
\hline & & $E$ & $6,00 \pm 0,34$ & $7,24 \pm 0,30$ & 4,13 & $<0,001$ \\
\hline & & $\mathrm{t}$ & 0,22 & 2,30 & - & - \\
\hline & & $\mathrm{P}$ & $>0,05$ & $<0,05$ & - & - \\
\hline \multirow{4}{*}{6.} & \multirow{4}{*}{$\begin{array}{l}\text { Double rope jumps, } 1 \\
\text { min (number of times) }\end{array}$} & $\mathrm{C}$ & $24,88 \pm 1,80$ & $26,94 \pm 1,72$ & 1,21 & $>0,05$ \\
\hline & & $\mathrm{E}$ & $24,20 \pm 1,78$ & $31,94 \pm 1,64$ & 4,66 & $<0,001$ \\
\hline & & $\mathrm{t}$ & 0,27 & 2,10 & - & - \\
\hline & & $\mathrm{P}$ & $>0,05$ & $<0,05$ & - & - \\
\hline
\end{tabular}

Note: $\mathrm{n}_{\mathrm{k}}-16 ; \mathrm{n}_{\mathrm{o}}-16$. $\mathrm{P}-0,05 ; 0,01 ; 0,001 . \mathbf{C}-$ control group; $\mathbf{E}$ - experimental group. $\mathrm{f}-15 \quad \mathrm{t}=2,131 \quad 2,947 \quad 4,073 \quad \mathrm{t}$ and $\mathrm{P}$ - statistical characteristics.

$$
\mathrm{f}-30 \quad \mathrm{t}=2,042 \quad 2,750 \quad 3,646 \quad \mathrm{r}=0,532
$$

At the same time, in the process of basic pedagogical research, various types of motor activities and activity in the studied groups of handball players unequally affected the manifestation of their coordination capabilities. So, the control group of handball players improved their results by the end of the yearlong study for all tests, but with their comparative analysis they are statistically unreliable with respect to the initial ones at $\mathrm{P}>0.05$. This fact testified to the fact that the traditionally used training tools and methods are not effective enough for the formation of such coordination capabilities of an applied nature in handball players of the control group. If we consider the dynamics of the development of the motor coordination process in the experimental group during the 
study period, then a completely different situation is observed in comparison with the results of the control group handball players.

So, the handball players of the experimental group, developing in programdesigned training sessions during the calendar year, had a positive and reliable dynamics of indicators for all tests by the end of the study compared to the initial data at a much higher significance level: at $\mathrm{P}<0.01-0.001$. And it is especially necessary to emphasize that, according to the final results, the handball players of the experimental group also significantly exceeded the achievements of the control group (at $\mathrm{P}<0.05$ ).

Thus, the targeted impact on the handball players of the experimental group of tools and methods laid down in the draft of our Program effectively influenced the formation of applied coordination abilities, the possession of which will contribute to the successful team-game specialization of these athletes.

Along with the psycho-motor, motor and coordination effective development of 12-13 years old handball players, we were interested in their sports and technical training, which also reflected the specialized coordination of their manifestations. At the same time, we believed that handball players of all game roles should be equally good at owning the ball during a game pass, dribbling the ball in difficult conditions of the game, be proficient in accuracy and throwing range, and also take coordinating and technical actions in difficult, specially created conditions (combined tests).

We also believed that this coordinationtechnical complex of tests would reliably reflect the possession of 12-13-year-old handball players by the basic technical methods of the game. The obtained data of the subjects and groups for the period of the main experiment are shown in Table 4. As can be seen from Table 4, at the beginning of the pedagogical experiment, the initial indicators were adopted, according to which both experimental groups in the statistical comparison were relatively uniform, at $\mathrm{P}>$
0.05. Further development of training events showed that both experimental groups (control and experimental) improved their performance by the end of the year-long study, but this improvement is not unambiguous.

Thus, in the control group of handball players, the available positive changes in the tested parameters for all control exercises (tests) are still unreliable at $\mathrm{P}>0.05$. While in the experimental group of handball players, positive changes are significant at $\mathrm{P}<0.05$ 0.001 .

At the same time, the handball players of the experimental group achieved the greatest improvement in technical results in the tests: throwing the ball for accuracy; throwing a tennis ball at a distance (at $\mathrm{P}<0.001$ ).

Thus, we can conclude that the specialized training process of 12-13 years old handball players of the experimental group, focused on their early game specialization, gives a positive effect of sports-game perfection.

Sports improvement and especially of a playful character with a positive emotional character enhances the functionality of all body systems and reliably ensures the intellectual development of athletes of any age. That is why, we consider it extremely important to study and improve the intellectual components of 12-13 years old handball players, which determine the potential of their individual capabilities when they are implemented in a gaming environment.

We also believe that the comprehensive functional-motor development of 12-13-yearold handball players and the improvement of such basic interdependent intellectual components as "attention", "perception", "memory", thinking "and imagination" will help them successfully demonstrate their abilities in competitive battles. In other words, a 12-13-year-old handball player can and should already possess sufficient age-related intellectual and applied coordination-motor potential for the possibility of successfully fulfilling his team-game role. 
Table 4. A comparative analysis of the results of testing the technical condition of 12-13 years old handball players of control and experimental groups for the period of the main study

\begin{tabular}{|c|c|c|c|c|c|c|}
\hline № & Types of Testing & 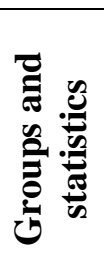 & $\begin{array}{c}\text { Initial indices } \\
\bar{X} \pm m\end{array}$ & $\begin{array}{c}\text { Final indices } \\
\bar{X} \pm m\end{array}$ & $\mathbf{t}$ & $\mathbf{P}$ \\
\hline \multirow{4}{*}{1.} & \multirow{4}{*}{$\begin{array}{l}\text { Dribbling } 10 \text { obstacles } \\
\text { by the ball on a } 30 \mathrm{~m} \\
\text { distance, }(\mathrm{sec})\end{array}$} & $\mathrm{C}$ & $37,00 \pm 1,03$ & $36,25 \pm 1,00$ & 0,77 & $>0,05$ \\
\hline & & $\mathrm{E}$ & $36,35 \pm 1,04$ & $33,37 \pm 0,96$ & 3,07 & $<0,01$ \\
\hline & & $\mathrm{t}$ & 0,44 & 2,07 & - & - \\
\hline & & $\mathrm{P}$ & $>0,05$ & $<0,05$ & - & - \\
\hline \multirow{4}{*}{2.} & \multirow{4}{*}{$\begin{array}{l}\text { Throws the ball for } \\
\text { accuracy, from a } \\
\text { distance of } 6 \mathrm{~m} .12 \\
\text { throws, (number of } \\
\text { hits) }\end{array}$} & $\mathrm{C}$ & $8,00 \pm 0,44$ & $8,50 \pm 0,42$ & 1,20 & $>0,05$ \\
\hline & & $\mathrm{E}$ & $8,25 \pm 0,41$ & $9,90 \pm 0,38$ & 4,23 & $<0,001$ \\
\hline & & $\mathrm{t}$ & 0,42 & 2,46 & - & - \\
\hline & & $\mathrm{P}$ & $>0,05$ & $<0,05$ & - & - \\
\hline \multirow{4}{*}{3.} & \multirow{4}{*}{$\begin{array}{c}\text { Throwing a tennis ball } \\
\text { at a distance, }(\mathrm{m})\end{array}$} & $\mathrm{C}$ & $34,00 \pm 0,88$ & $35,74 \pm 0,84$ & 2,10 & $>0,05$ \\
\hline & & $\mathrm{E}$ & $34,80 \pm 0,86$ & $38,49 \pm 0,77$ & 4,67 & $<0,001$ \\
\hline & & $\mathrm{t}$ & 0,65 & 2,41 & - & - \\
\hline & & $\mathrm{P}$ & $>0,05$ & $<0,05$ & - & - \\
\hline \multirow{4}{*}{4} & \multirow{4}{*}{$\begin{array}{l}\text { From the free throw } \\
\text { line, } 15 \text { goals to be } \\
\text { scored, (number of } \\
\text { times) }\end{array}$} & $\mathrm{C}$ & $11,00 \pm 0,74$ & $11,59 \pm 0,72$ & 0,83 & $>0,05$ \\
\hline & & $\mathrm{E}$ & $11,43 \pm 0,75$ & $13,70 \pm 0,66$ & 3,29 & $<0,01$ \\
\hline & & $\mathrm{t}$ & 0,41 & 2,15 & - & - \\
\hline & & $\mathrm{P}$ & $>0,05$ & $<0,05$ & - & - \\
\hline \multirow{4}{*}{5} & \multirow{4}{*}{$\begin{array}{c}\text { Comprehensive } \\
\text { exercise for all } \\
\text { handball players, }(\mathrm{sec})\end{array}$} & $\mathrm{C}$ & $35,00 \pm 0,46$ & $34,67 \pm 0,45$ & 0,75 & $>0,05$ \\
\hline & & $\mathrm{E}$ & $34,78 \pm 0,47$ & $33,45 \pm 0,38$ & 3,17 & $<0,05$ \\
\hline & & $\mathrm{t}$ & 0,33 & 2,07 & - & - \\
\hline & & $\mathrm{P}$ & $>0,05$ & $<0,05$ & - & - \\
\hline \multirow{4}{*}{6} & \multirow{4}{*}{$\begin{array}{l}\text { Comprehensive } \\
\text { exercise for the } \\
\text { goalkeeper, }(\mathrm{sec})\end{array}$} & $\mathrm{C}$ & $20,00 \pm 0,61$ & $19,51 \pm 0,58$ & 0,84 & $>0,05$ \\
\hline & & $\mathrm{E}$ & $19,86 \pm 0,63$ & $17,83 \pm 0,54$ & 3,91 & $<0,01$ \\
\hline & & $\mathrm{t}$ & 0,16 & 2,13 & - & - \\
\hline & & $P$ & $>0,05$ & $<0,05$ & - & - \\
\hline
\end{tabular}

Note: $\mathrm{n}_{\mathrm{k}}-16 ; \mathrm{n}_{\mathrm{o}}-16 . \mathrm{P}-0,05 ; 0,01 ; 0,001 . \mathbf{C}$ - control group; $\mathbf{E}$ - experimental group.

$$
\begin{array}{lllll}
\mathrm{f}-15 \mathrm{t} & =2,131 & 2,947 & 4,073 & \mathrm{t} \text { and } \mathrm{P} \text { - statistical characteristics.. } \\
\mathrm{f}-30 \mathrm{t}=2,042 & 2,750 & 3,646 & \mathrm{r}=0,532
\end{array}
$$

We also believe that the specialized, applied motor and coordination development of handball players in their playing role according to the Program we have developed will contribute to the improvement of the above cognitive abilities, as an integral part of their intellectual development.

To determine the intellectual development of 12-13 years old handball players, we chose such a cognitive component as "attention", the proper concentration and stability of which can positively affect the successful resolution of the current planned and unforeseen situation in a competitive match.

At the same time, to assess the sustainability of attention of handball players, from numerous options, we used the "Bourdon-Anfimov proof-reading test", which, 
in our opinion, is a fairly simple and at the same time an effective letter test.

The integrated data of the main pedagogical experiment on the sustainability of attention identified using the BourdonAnfimov proof-reading test are presented in Table 5.

At the same time, the stability of "attention" of handball players was determined using such intermediate indicators as: "productivity of work" (the total number of letters scanned for each minute and in general for 10 minutes was calculated); the number of correctly underlined letters $\mathrm{K}$ and $\mathrm{P}$; the number of letters to be crossed out; accuracy of task performance (in\%); accuracy assessment (in points); assessment of productivity (in points).

All intermediate indicators were calculated by formulas and compared with the corresponding Tables.
The data in Table 5 show that in the control and experimental group of handball players, during the period of the one-year experiment, there were positive changes in the intermediate indicators, reflecting their degree of attention stability. However, a comparison of the integrated indicators for "accuracy assessment" and "productivity assessment", reflecting the final "attention sustainability assessment" of the handball players tested, indicates that the qualitative level of such an assessment in the control group has quantitatively improved slightly, but the quality has remained the same. At the same time, in the experimental group, this qualitative indicator, over the period of the experiment, grew more significantly from "below average" to "average" level (paragraph 5, Table 5).

Table 5. Integrated indicators of component variables for the final assessment of the stability of attention of handball players of the studied groups in the main pedagogical experiment

\begin{tabular}{|c|c|c|c|c|c|}
\hline \multirow{4}{*}{ № } & \multirow{4}{*}{$\begin{array}{l}\text { Types of text sample } \\
\text { processing procedures }\end{array}$} & \multicolumn{4}{|c|}{$\begin{array}{l}\text { Indicators of the constituent components of a } \\
\text { qualitative level of attention sustainability }\end{array}$} \\
\hline & & \multicolumn{2}{|c|}{$\begin{array}{l}\text { Control group } \\
\left(\mathrm{n}_{\mathrm{k}}-16\right)\end{array}$} & \multicolumn{2}{|c|}{$\begin{array}{l}\text { Experimental groupp } \\
\left(\mathrm{n}_{\mathrm{o}}-16\right)\end{array}$} \\
\hline & & $\begin{array}{c}\text { Initial } \\
\text { indices }\end{array}$ & Final indices & $\begin{array}{l}\text { Initial } \\
\text { indices }\end{array}$ & $\begin{array}{c}\text { Final } \\
\text { indices }\end{array}$ \\
\hline & & $\bar{X}$ & $\bar{X}$ & $\bar{X}$ & $\bar{X}$ \\
\hline 1. & $\begin{array}{c}\text { Number of letters viewed in } 10 \\
\text { minutes }\end{array}$ & 1033,00 & 1200,00 & 1095,00 & 1644,00 \\
\hline 2. & $\begin{array}{l}\text { Number of correctly crossed } \\
\text { out letters }\end{array}$ & 56,48 & 63,23 & 56,87 & 88,57 \\
\hline 3. & $\begin{array}{l}\text { The number of letters to be } \\
\text { crossed out }\end{array}$ & 75,00 & 87,00 & 75,47 & 120,55 \\
\hline 4. & $\begin{array}{l}\text { Attention sustainability } \\
\text { assessment, points }\end{array}$ & 5,40 & 6,15 & 5,50 & 8,00 \\
\hline 5. & $\begin{array}{l}\text { Qualitative level of attention } \\
\text { sustainability assessment }\end{array}$ & $\begin{array}{l}\text { below the } \\
\text { average }\end{array}$ & $\begin{array}{l}\text { below the } \\
\text { average }\end{array}$ & $\begin{array}{l}\text { below the } \\
\text { average }\end{array}$ & average \\
\hline
\end{tabular}


Table 6. Qualitative assessment of the sustainability of attention of 12-13 year old handball players according to the points received

\begin{tabular}{|c|c|}
\hline Scoring & Attention Sustainability Characterization \\
\hline $1-3$ & Low level of attention sustainability \\
\hline $4-7$ & Below the average level of attention sustainability \\
\hline $8-11$ & Average level of attention sustainability \\
\hline $12-15$ & Above the average level of attention sustainability \\
\hline $16-19$ & High level of attention sustainability \\
\hline
\end{tabular}

Moreover, we also found it interesting to find out how the athletes' attention was changed per minute in the total time tested by identifying the indicated letter graphics. These data are shown in Figure 1. As can be seen from Figure 1, the graphs of the initial and final indicators of the control group and the initial indicators of the experimental group are almost identical and show a relatively stable dynamics of increased fatigue of the central nervous system in handball players by the end of the test in the proof-reading test. At the same time, the graph of per-minute results of the final indicators of the experimental group of handball players in the dynamics of decline is more gentle and reflects a decrease in the fatigue of these athletes to a much lesser extent.

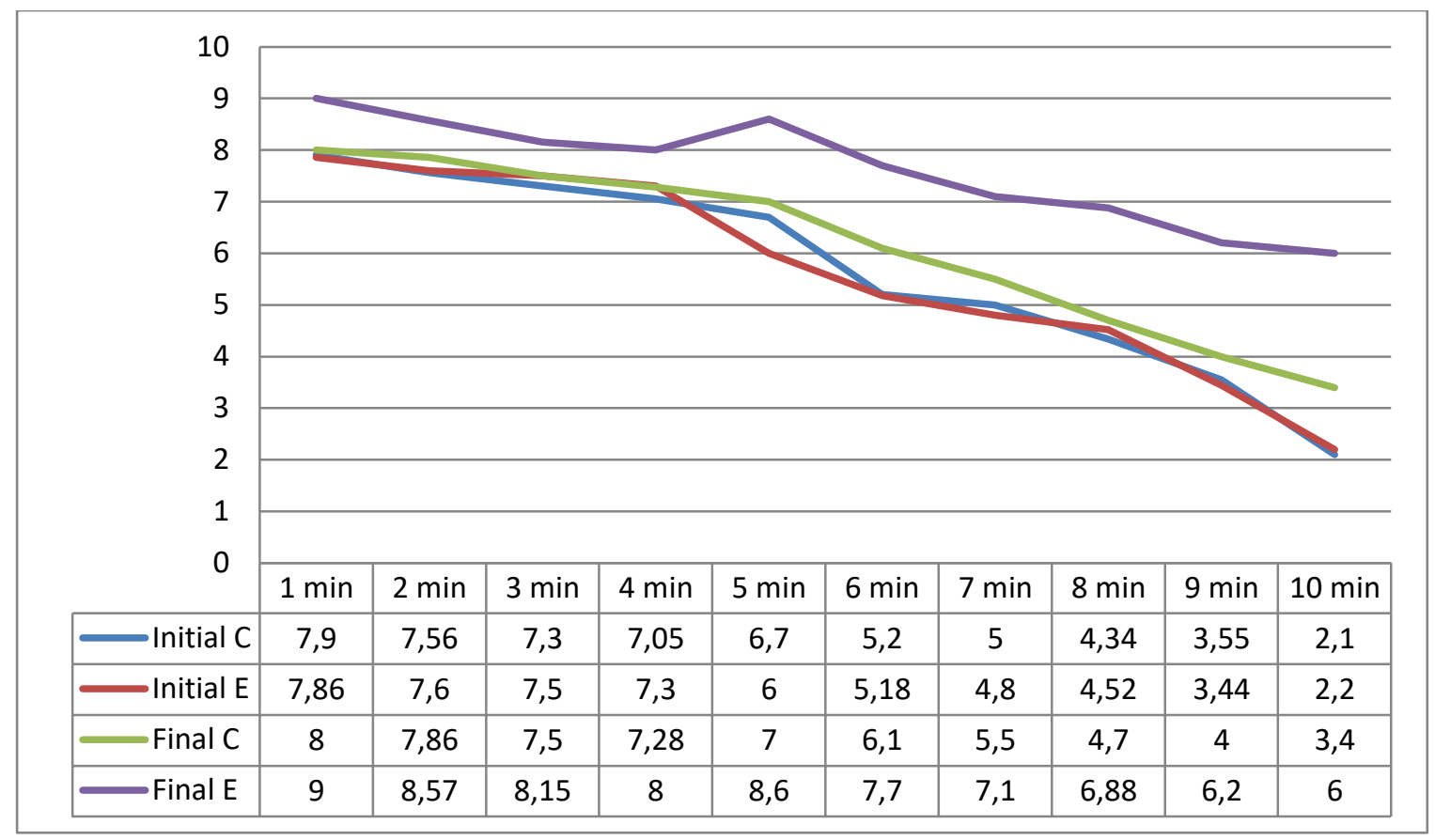

Note: $\mathrm{C}$ - control group; $\mathrm{E}$ - experimental group.

Fig.1. The dynamics of a decrease in the average indicators for identifying the indicated graphics of letters reflecting the corresponding concentration of attention of 12-13 years old handball players in the per-minute mode of the total tested time 
Thus, the data presented in the above Tables and Figures indicates that with the directed motor complex coordination of the development of 12-13 year-old handball players of the experimental group, their intellectual potential improves qualitatively, and therefore the stability of their attention in that team role in various situations will be more successful.

\section{Conclusions.}

1. Our main, one-year pedagogical experiment to determine the effectiveness of a specialized sports program for the training of 12-13 year-old handball players showed that the means and methods of sports improvement, taking into account the early game specialization, had a positive effect on development of all studied types of abilities of subjects of the experimental group.

2. Thus, in the experimental group of handball players, the morpho-functional status of the subjects increased reliably during the experiment, at a level of $\mathrm{P}<0.05-0.01$, indicators of psychomotor functionality improved.

3. The directed impact on the handball players of the experimental group of tools and methods laid down in the draft of our Program effectively influenced the formation of applied motor coordination skills, the possession of which will contribute to the successful teamgame specialization of these athletes. Moreover, in the experimental group of handball players, positive changes are significant at $\mathrm{P}<0.05-0.001$.

4. Handball players of the experimental group achieved significant improvement in sports and technical results practically in tests ( $\mathrm{P}<0.05-0.01)$, but especially in such tests as: throwing the ball for accuracy; throwing the ball at a distance (at $\mathrm{P}<0.001$ ).

5. The directed motor and difficult coordination development of 12-13 years old handball players of the experimental group had a positive effect on their intellectual potential, which reached "above average" level, which means that the stability of their attention in that team role in various situations will be more successful and productive.

6. The specialized training program for 12-13 years old handball players of the experimental group developed by us, focused on their early game specialization, gives a positive effect in their sports and game improvement.

\section{References:}

1. Вережан Р. (2014). Содержание предсоревновательного этапа подготовки линейного игрока в гандболе 12-13 лет. B: Materialele Conferinţei Ştiinţifice Internaţionale consacrate Zilei Mondiale a Calității „Probleme actuale privind perfecționarea sistemului de învăţământ în domeniul culturii fizice". Chişinău: USEFS, , c. 183-188.

2. Вережан Р. (2013). Программирование предсоревновательного этапа подготовки линейного игрока в гандболе 12-13 лет. B: Materialele Conferinţei Ştiinţifice Internaţionale a doctoranzilor. „Cultura fizică: probleme ştiinţifice ale învăţământului şi sportului”, ediţia VII. Chişinău: USEFS, c. 267-269.

3. Вережан Р. (2014). Функциональное состояние подготовки линейного игрока в гандболе 12-13 лет в предсоревновательном этапе. В: Materialele Conferinţei Ştiinţifice Internaţionale „Probleme actuale privind perfecţionarea sistemului de învăţământ în domeniul culturii fizice" consacrate Zilei Mondiale a Calităţii. Chişinău: USEFS, c.189-193.

4. Вережан Р. (2016). Развитие физических качеств у гандболистов 12-13 лет. В: Materialele Congresului Ştiinţific Internaţional „Sport. Olimpism. Sănătate”. Chişinău: USEFS, c. 153-159. 
5. Верхошанский Ю.В. (1966). Динамическая структура сложных двигательных действий. В: Теория и практика физической культуры, № 9, с. 10.

6. Игнатьева В.Я. и др. (2001). Гандбол: Программа для ДЮСШ и СДЮШОР по гандболу. Москва. Министерство образования Российской Федерации. 135 с.

7. Игнатьева В.Я. и др. (2001). Особенности технической подготовленности российских гандболисток вратарей. В: Теория и практика физической культуры, №9, с. 17-19.

8. Игнатьева В.Я. (2001). Гандбол. Серия «Азбука спорта». Москва: Физкультура и спорт. $192 \mathrm{c.}$

9. Игнатьева В.Я. и др. (2003). Гандбол. Программа для системь дополнительного образования детей: детско-юношеских спортивных школ, специализированных детскоюношеских спортивных школ олимпийского резерва. Москва: Советский спорт. $116 \mathrm{c.}$

10. Ильин Е.П. (1980)Психология физического воспитания. Москва: Просвещение. 199 с.

11. Манолаки В.В. (2012). Особенности формирования спортивного отбора детей в дзюдо на начальном этапе подготовки. Автор. дис. д-ра пед. наук. Кишинев: USEFS. 30 с.

12. Матвеев Л.П. (1997). Общзая теория спорта. Москва: Воениздат. 230 с.

13. Матвеев Л.П. (1982). О некоторых проблемах теории и практики физической культуры. В: Теория и практика физ. культуры, № 7, с. 5-8.

14. Матвеев Л.П. (1999). Основы общей теории спорта и системы подготовки спортсменов. Киев: Олимпийская литература. 320 с.

15. Матвеев Л.П. (2000). Модельно-целевой подход $\kappa$ построению спортивной подготовки. В: Теория и практика физ. Культуры, №2, с. 28-37.

16. Матвеев Л. П. (2005). Общзая теория спорта и ее прикладные аспекты. СанктПетербург: Лань. 384 с.

17. Матвеев Л.П. (2008). Теория и методика физической культуры.. Москва: Советский спорт. 544 с.

18. Набатникова М.Я. (1980). Теоретические аспекты исследования системы подготовки юных спортсменов. В: Теория и практика физической культуры, № 4, с. 21-22.

19. Озолин Н.Г. (2011). Современная система спортивной тренировки. Москва: Физкультура и Спорт. 479 с.

20. Платонов В. Н. (2005). Система подготовки спортсменов в олимпийском спорте. Общая теория и ее практические приложения. Учебник тренера высшей квалификации. Москва: Советский спорт. 820 с.

21. Теория и методика физического воспитания. Учебник для институтов физической культурыл. Том І. Под ред. Матвеева Л.П. и Новикова А.Д. Москва: Физкультура и спорт, 1976. 304 c.

22. Филин В.П., Фомин Н.А. (1980). Основы юношеского спорта. Москва: Физкультура и спорт. 255 с. 